\title{
Youth Political Participation, Good Governance and Social Inclusion in Nigeria: Evidence from Nairaland
}

\author{
Akinyetun Tope Shola
}

\begin{abstract}
As the Nigerian population continues to increase, so does the number of youth. The population of youth (18-35 years) in Nigeria is 52.2 million (i.e. about $28 \%$ of total population) and more than the entire population of Ghana, London and Benin Republic put together. In spite of the prospects that this number holds, young people in Nigeria are largely marginalized from governance, leaving them helpless to counter their continued exclusion. This is evidenced by the lower percentage of youth that hold political and leadership positions in the country. The purpose of this study was to examine the relationship between youth political participation, good governance, and social inclusion in Nigeria. Using a quantitative approach, 1,208 youth aged 18-35, selected from Nairaland, participated in the study. Data gathered was analyzed with Spearman Correlation Coefficient and the result indicates that there is significant positive relationship between youth political participation and good governance in Nigeria $\left(\mathrm{r}_{\mathrm{s}},(1206)=.615, \mathrm{p}<.001\right)$ and that there is significant positive association between youth political participation and social inclusion in Nigeria $\left(\mathrm{r}_{\mathrm{s}}(1206)=.875, \mathrm{p}<.001\right)$. It was recommended that the government should create Leadership and Democratic Institutes [LDI] across the states of the Federation and establish an Online Leadership Orientation Agency [OLOA] to utilize various social networking sites to provide free leadership courses, webinars, and orientation on the art of governance and the promotion of social inclusion among youth.
\end{abstract}

Keywords: good governance, social inclusion, political participation, youth

\begin{abstract}
Akinyetun, Tope Shola teaches Political Science at Adeniran Ogunsanya College of Education, Oto/Ijanikin, Lagos State, Nigeria. His research interest includes - but is not limited to - identity politics, violence, terrorism, youth studies and development studies. In addition to being a Rosalind Member of the London Journal Press, he also reviews for notable journals such as New Media Society (Sage Publications). His recent publications are "A theoretical assessment of Boko Haram insurgency in Nigeria from relative deprivation and frustration-aggression perspectives" by African Journal of Terrorism and Insurgency Research (Adonis \& Abbey, 2020) and "Identity politics and national integration in Nigeria: The sexagenarian experience" by African Journal of Inter/Multidisciplinary Studies (Durban University of Technology, South Africa, 2020).
\end{abstract}




\section{Introduction}

The world today has the largest number of young people in history, with half of the world population under the age of 30. It is interesting to note that 90 percent of these young people, running into billions, are in the developing world. This underscores the significance of engaging youth for personal and societal development in response to global pressing challenges (United Nations Educational, Scientific and Cultural Organization (UNESCO), 2013)). As the Nigerian population continues to increase, so does the number of youth continue to grow in what has been described as the 'youth bulge'. The upsurge in the youth population - although a strain to education systems and labour markets - also has an economic value provided that these youth are meaningfully engaged. As such, it behooves any government to take advantage of the teeming population of youth to create a demographic dividend (a declining dependency ratio), and harness such a dividend for increased productivity and a burgeoning labour force. To be specific, the population of youth (18-35 years) in Nigeria is 52.2 million (i.e. circa $28 \%$ of total population) with 52.8:48.2 female to male ratio (National Bureau of Statistics (NBS), 2018).

Having a growing youth population may translate into a large and active work force, yet, it may also result in a disaster with an upsurge in the crime rate, an increased dependency ratio and worryingly, widespread poverty. This makes it all the more important for the government to actively engage youth to create an integrated and inclusive society (NBS, 2018). As Zohdy (2017) argues, social inclusion of youth in governance is instrumental in avoiding societal costs that comes with the exclusion of youth, such as lower voter turnout rates, a loss of several percentages of GDP, violence, extremism, crime, and instability. Most youth efforts, rather than treating youth as partners or agents of governance, regard them as mere recipients of the dividends of governance.

Contrarily, Galstyan (2019) opine that young people are not interested in politics because politics does not represent the problems that are important to them. In the same vein, Offiong (2018) argues that Nigerian youths' efforts at leadership is a futile exercise because generally, they are too divided along ethnic lines to clamour for national integration. The youth lack the financial capacity to contest and would rather prefer to remain politician's lackeys as advanced democracies still elect the older generation as their leaders. However, Offiong's submission is wrong. For one, Offiong assumes that political participation is restricted to contesting in an election, of voting in a government. He also failed to acknowledge that the President of France, Emmanuel Macron (who became President at the age of 39 years) does not belong to the older generation as he presumed. Thinking differently from Offiong, Badmus (2018) avers that Nigerian youth are ready to be actively involved in politics, especially as the world is beginning to beam their light on youth activities in Nigeria, while Olufowobi (2018) opines that all that is needed to improve youth participation in politics is an enabling environment.

Research also suggests that the new millennium has witnessed a withdrawal of citizens from democratic participation across a range of democracies. The political engagement of young people has been generally lower in comparison to the general population (Pontes, Henn \& Griffiths, 2019). Although, O'Toole (2015) disagrees with this stance, arguing that in spite of youths' seeming lack of interest in formal political activities, they are attracted to, and often engage in, informal and alternative modes and styles of participation in political life. Zohdy (2017), however, maintains that engaging youth as leaders of development is by far the least utilized and most untapped approach in democratic countries. 
The Department for International Development (DFID) (2010) submits that there is a major gap that is evident between youth who have been offered services as beneficiaries and when they have been politically engaged as true leaders and drivers of their own development and that of their community. The latter has consistently resulted in the greatest impact. As the National Youth Policy (2019) would have us believe, Nigerian youth are faced with a myriad of challenges including poverty, multidimensional discrimination, unemployment, barriers to education, and limited opportunities that constitutes a bane to their political participation and inclusion, thus leading to a lower percentage of youth that hold political and leadership positions. However, most of the present political leaders became exposed to politics during their youthful years. It is evident from the foregoing that young people in Nigeria are largely marginalized from governance and most of them feel helpless about their continued exclusion. It is upon this premise that it becomes important to assess youth roles in governance and social inclusion. It is against this backdrop that this study assesses youth political participation, good governance, and social inclusion in Nigeria.

\section{Literature Review}

\section{Youth Political Participation}

Youth political participation is a concept made up of two distinct terms: youth and political participation, which requires explaining if the concept if to make any meaning. The notion of youth has been defined in a number of ways in the literature. For instance, while the United Nations defined youth as anyone between the age brackets of 15-24, the World Bank defined youth as individuals aged 12-24. Galstyan maintains that youth is a period of "transition from dependency to independence", while Hilker and Fraser maintain that youth is a transitional stage between childhood and adulthood, rather than as a rigid construct based on age. Meanwhile, due to the political, sociocultural and economic realities in Africa, these age brackets have been described as too narrow. As a result, Nigeria's 2009 National Youth Policy defined youth as persons of age 18 to 35 years (Galstyan, 2019:3, Hilker \& Fraser, 2009; National Youth Policy, 2019; United Nations, 2013). Therefore, youth as used in this study refers to persons between the ages of 18 and 35 years. As well, the terms youth and young people are used interchangeably.

Political participation is yet another contentious concept in the literature. According to Verba and Nie (1972, p. 2), political participation refers to "those activities by private citizens that are more or less directly aimed at influencing the selection of governmental personnel and/or the actions they take". Van Deth (2014, p. 5) describes the concept using a range of features: 1) it is an activity; 2) it is voluntary and not ordered by a ruling class or required by law; 3) it refers to people in their role as non-professionals or amateurs; and 4) it concerns government, politics, or the state.

According to Sida (2010), youth political participation refers to the involvement of young people in political activities, civic life, active citizenship, and policy making. This could take several forms, including serving on a local government council, voting in an election, or participating in the budget process of a local government. 
As Ibezim (2019) notes, youth participation in politics in Nigeria is bedeviled by a myriad of challenges, chief among which is, a lack of understanding of the benefits that youth political participation holds. The author goes further to state that unemployment, social exclusion, limited capacity, resource, and tools are other problems facing youth. According to Luhrmann (2013), as the 2011/2012 Arab States popular uprisings have showed, the inclusion of youth in formal politics is essential. In countries in transition (i.e. Nigeria), novel ideas and innovate leadership can help to overcome dictatorial practices. It is also important to pay attention to individual capacity development. While doing so, the capacities of organizations and the degree to which an environment enables individuals and institutions to participate in political processes should be given utmost consideration. This argument is corroborated by Mengistu (2017) who asserts that due to abysmal youth political participation in Africa, and by extension Nigeria, the majority of young people are vulnerable to enlistment for violence against a government. The complicity of young people in the establishment of the Revolutional United Front (RUF) in Sierra Leone, is a case in point.

Youth political participation is more than just voting in an election. As Farthing (2012) argues, youth political participation could take the following forms:

a. Participation as a rights-based practice;

b. Participation as a mechanism of empowerment of young people;

c. Participation as a guarantee of efficiency in policy, practice and services; and

d. Participation as an instrument of young people's development.

Beyond the conventional forms of political participation such as voting, campaigning, holding a membership, performing voluntary work, and taking part in civic responsibility, demonstrations, and community participation (Galsyan, 2019), new forms of participation have been documented in the literature (Pleyers \& Karbach, 2014). They include:

a. hacking and distributed denial of service (DDOS) attacks: This is a form of protest aimed at shutting down online servers and restricting access to internet services;

b. clicktivism and slacktivism: This is an invitation to click specific links to express agreement with a particular statement. Although, it could sometimes be voluntary;

c. online campaigning: Social network is increasingly becoming popular for its use in starting a cause and gain followership;

d. crowdsourcing and crowdfunding: This rests on the use of the 'crowd' as feedback mechanism for ideas, feedback, project design, and financial support.

e. liquid democracy/LiquidFeedback: As a new system, it allows users to make a collective decision by granting each individual the chance of voting and 'democratically' choosing their representative; and 
f. BarCamp: This is an online conference system where the participants themselves design the programme and its sessions (Pleyers and Karbach 2014).

The above is evidence that the concept of youth political participation is evolving over time and is therefore worthy of continued research and policy making.

\section{Good Governance}

To define good governance, it is important to have a grasp of the term governance. Udeh (2017:149) submits that governance "involves the dynamics of transforming societal needs into concrete programmes... governance means the development of governing styles in which boundaries between public and private sectors have become blurred and the needs of society increasingly met." According to Adegbami \& Adepoju (2017), governance refers to acquiring political power so as to direct a state's economic power towards development. It is concerned about utilizing a state's resources for the development of that state. Hence, the concept "good governance" involves public officers managing public resources judiciously and in a "good" way. To the UNDP (2002), good governance involves maintaining transparency, accountability, probity and upholding the rule of law in the exercise of power. Udeh (2017) adds that good governance connotes an array of activities such as improved service delivery, citizens' participation in decision making, democracy, the rule of law, independence of the judiciary, electoral integrity, freedom of the press, equality before the law and inclusion of the maligned groups in the political process. Udeh further argues that good governance also guarantees gender equality as well as accountable and transparent governance.

\section{Social Inclusion}

The term inclusion may be used to refer specifically to the integration of traditionally marginalized, under-represented and/or at-risk subgroups in broader populations (Zohdy, 2017). According to the United Nations (2016, p. 20), social inclusion is defined as "the process of improving the terms of participation in society, particularly for people who are disadvantaged on the basis of age, sex, disability, race, ethnicity, origin, religion, or economic or other status, through enhanced opportunities, access to resources, voice and respect for rights." Social inclusion is enshrined in the Sustainable Development Goal for 2030 Agenda and involves improving access to economic resources and beyond. As the World Bank (2013, pp. 3-4) notes, social inclusion is "the process of improving the terms for individuals and groups to take part in society" and "the process of improving the ability, opportunity, and dignity of people, disadvantaged on the basis of their identity, to take part in society." 
In the opinion of Ozer (2011), social inclusion involves making sure that individuals participate in social life devoid of delimiting factors such as lack of education and poverty. To Edwards (2008, p. 17), "social exclusion and youth participation are considered to be two opposing concepts, and it is emphasized that social inclusion policies cannot be successful unless they ensure youth participation."

Youth Political Participation, Good Governance and Social Inclusion

Research suggests that even though there is a decline in youth participation in formal politics, young people are increasingly self-organizing more informal movements and activities. Many young people are organizing fluid social movements across borders and around issues of common concern. Thus, the political leaders should recognize and adapt to this shift in order to better support powerful, organic, youth-led efforts for social change and good governance (Rhize, 2016). As Zohdy (2017) notes, youth participation should involve working with them in governance, as well as the people around them to bridge the gap of eroding trust. Giving the youth a voice in governance and decision making will help them fulfill their individual potential, avoid negative behaviors, contribute to the well-being of the society, and create institutional capacity. Zohdy further argues that youth participation is more effective when treated as a means to an end. This is better understood in the author's words:

The most effective citizen participation efforts tend to be those that design participation not as an end in and of itself. A broader base of both citizens and government officials are more likely to participate and see value in such efforts if they are targeted toward solving specific, concrete, and tangible lived problems (for example, poor quality basic services like education, health, sanitation and transportation). This principle can/should also be applied to inform youth political participation efforts. Young people and their adult counterparts will generally be more likely to participate and to see value in their participation if it is structured around meaningful opportunities to change material conditions, decisions/policies, or other concrete outcomes, than general participation efforts not linked directly to solving actual problems in people's lives (p. 9).

To be sure, young people have proven to be productive in contributing to a better world as evidenced in their commitment to fulfilling the Sustainable Development Goals (SDGs), in addition to tackling some of the greatest challenges their generation is facing, such as inequality and climate change. Youth-led efforts tend to be energetic and creative, and often lead to promising outcomes. Youth political participation should be targeted at comprehensive inclusion (political, economic and social inclusion). It is not enough to educate or employ youth to prevent them from engaging in nefarious activities. Rather, many of the rare young people who do engage in political violence do so because of experiences of injustice (feelings of political exclusion), not necessarily because they are less educated or unemployed. So, any 
programs seeking to prevent youth participation in violence must seriously consider how to promote their political, economic and social inclusion (Zohdy, 2017). By and large, young people must be regarded as contributory participants in democratic processes and practices. Youth participation in developmental processes, including politics and governance, is a fundamental democratic right. It is also essential to note that youth political participation transcends voting but also involves several politically related activities undertaken by youth both online and offline.

Political participation is about having the wherewithal and opportunity needed to influence decision making as well as engaging in actions and activities so as to contribute to building a better society. There is sufficient evidence from around the world to argue that young people have asserted their role, influence and importance in governance by championing political causes and making giant strides. Young people are leaving their footprints in the sands of time by revolutionizing the status quo and provoking governance structures that seek to deepen democratic precepts (Rhize, 2016). Rhize's assertion is an insight into the potentials that the Nigerian youth hold, especially for governance, democratic consolidation and inclusion.

In promoting social inclusion, youth are useful in acting as active researchers who could help identify their community needs while also building their capacities with guidance from adult mentors and leaders, towards addressing these needs. This should begin with identifying existing youth leaders, and nurturing new youth leaders by promoting supportive networks of parents, teachers, and others that help build youth capacity and agency to lead. As Luhrmann (2013) noted, it was Kofi Anan who said:

No one is born a good citizen; no nation is born a democracy. Rather, both are processes that continue to evolve over a lifetime. Young people must be included from birth. A society that cuts itself off from its youth severs its lifeline; it is condemned to bleed to death (p.1).

Placing the above quotation in context, good citizenship and participatory democracy are not accidental attributes, neither are acquired as givens. Rather, they are consciously developed over time. That is, the notion that Nigerian youth are not ready for leadership given their inexperience, ignorance, pride, and immaturity (Offiong, 2018) holds no water, and in the least, is inconsequential.

\section{Objectives of the Study}

Considering the significance of good governance and social inclusion to Nigerian politics, it is imperative to underscore the role of the youth in the balance. Thence, the aim of this study is to examine youth political participation and good governance in Nigeria and youth political participation and social inclusion in Nigeria. 


\section{Methods}

To examine the hypotheses, quantitative data was gathered for this study. The study adopted an online survey design in its data gathering process from a convenience sampling of youth. This method was embraced because: 1) web questionnaires are less expensive to administer, can accommodate a large group, and gives access to real-time information (Akinyetun, 2016); and 2) the prevalent Coronavirus Pandemic (as at the time of carrying out this study) made it difficult to utilize pencil-and-paper survey or engage in physical administration of the instrument. The study was conducted through the Nairaland (www.nairaland.com). Nairaland is an online discussion forum created by Seun Osewa in 2005 with the aim of being the largest online community for Nigerians.

Nairaland has a visitation membership of $32 \%$ of the entire population (i.e. 64 million people); $3 \%$ of Nigerian internet users and an average of 12,000 daily visits. Nairaland is ranked the second most visited indigenous website in Nigeria (after bet9ja.com) and 790 in global internet traffic and engagement in April, 2020 (Alexa, 2020; Obi, 2020; www.nairaland.com). It is in light of youths' level of engagement and usage of Nairaland that the forum was selected as a platform to disseminate the research instrument. To do this, the authors created an online questionnaire using Google Forms and shared the link on the site. The study also adopted a snowball sampling technique to ensure that participants involved several other participants in the study. Based on our categorization of youth as belonging to the age group of 18-35, the entries with above 35 years of age were treated as invalid. As a result, a total of 1208 participants partook in the study.

\section{Participants}

The sample $(\mathrm{n}=1208)$ comprised more male $(62.9 \%)$ than female participants, and the majority (58.3) of the participants were between 18 years and 26 years of age. An overwhelming majority (74\%) reportedly have a post-secondary school education while slightly more than half of the participants (55.2\%) are unemployed. A summary of the sociodemographic variables is presented in Table1.

\section{Materials}

A questionnaire entitled "Youth Political Participation, Good Governance and Social Inclusion Questionnaire" [YPPGGSIQ] was used in this study and contains three parts. Part I comprised items assessing participants' sociodemographic characteristics such as: gender, age group, education level and employment state. Part II contains set of questions aimed at testing youth political participation with a 5 -point reverse coded response scale ( $1=$ absolutely untrue, $2=$ untrue, $3=$ prefer not to say, $4=$ true, $5=$ absolutely true) while part II contains questions to test for good governance and social inclusion with a 5-point reverse coded response scale ( $1=$ strongly disagree, $2=$ disagree, $3=$ neither agree nor disagree, $4=$ agree, $5=$ strongly agree). Choosing a 5-point response scale has several merits. It makes the instrument less confusing, lowers respondent frustration level, is more reliable, and allows respondents to express their views quickly (Abdelrahim, 2019). 
Reliability

Reliability in the instrument designed for the present study was tested for internal consistency (i.e., Cronbach's coefficient alpha). Cronbach's alpha $(\alpha)$ tests showed youth political participation $(\alpha=0.776)$, good governance $(\alpha=747)$, and social inclusion $(\alpha=.783)$. Since the acceptable reliability coefficient is .70 or higher, the various items of the instrument were considered reliable.

\section{Statistical Analyses}

The statistical analyses which comprise of (1) inferential descriptive statistics for sociodemographic data (Table 2) and (2) nonparametric data analyses (i.e. Spearman Correlation Coefficient; Tables 2 and 3), was carried out with IBM SPSS v.22, and adopted a significance level of $\mathrm{p}<0.05$.

\section{Results and Discussion}

This section outlines the result of the study. The results from the Spearman Correlation summarized in Table 2 indicate that there was significant positive relationship between youth political participation and good governance in Nigeria $\left(r_{\mathrm{s}}(1206)=.615, p<.001\right)$. Meanwhile, concerning youth political participation and social inclusion, the Spearman Correlation summarized in Table 3 show that there was a significant positive association between youth political participation and social inclusion in Nigeria $\left(r_{\mathrm{s}}(1206)=.875, p<.001\right)$.

Table 1: Sociodemographic Variables of the Participants

\begin{tabular}{|c|c|c|}
\hline Characteristic & Frequency & Percent \\
\hline \multicolumn{3}{|l|}{ Gender } \\
\hline Male & 760 & 62.9 \\
\hline Female & 448 & 37.1 \\
\hline \multicolumn{3}{|l|}{ Age group } \\
\hline 18-26 years & 704 & 58.3 \\
\hline $27-35$ years & 504 & 41.7 \\
\hline \multicolumn{3}{|l|}{ Education level } \\
\hline Primary & 36 & 3 \\
\hline Secondary & 278 & 23 \\
\hline \multicolumn{3}{|c|}{ Employment status } \\
\hline Post-secondary & 894 & 74 \\
\hline Employed & 541 & 44.8 \\
\hline Unemployed & 667 & 55.2 \\
\hline
\end{tabular}

Source: Survey, 2020 
Table 2: Correlations

\begin{tabular}{|ll|r|r|}
\hline & & \multicolumn{1}{l|}{$\begin{array}{l}\text { Youth } \\
\text { political } \\
\text { participation }\end{array}$} & $\begin{array}{l}\text { Good } \\
\text { governance }\end{array}$ \\
\hline Spearman's rho $\begin{array}{l}\text { Youth } \\
\text { political } \\
\text { participation }\end{array}$ & Correlation Coefficient & 1.000 & $.615^{*}$ \\
& Sig. (2-tailed) &. & .000 \\
& $\mathrm{~N}$ & 1208 & 1208 \\
\hline $\begin{array}{lll}\text { Good } \\
\text { Governance }\end{array}$ & Correlation Coefficient & $.615^{*}$ & 1.000 \\
& Sig. (2-tailed) & .000 &. \\
& $\mathrm{~N}$ & 1208 & 1208 \\
\hline
\end{tabular}

*. Correlation is significant at the 0.05 level (2-tailed).

Table 3: Correlations

\begin{tabular}{|c|c|c|c|c|}
\hline & & & \begin{tabular}{|l|} 
Youth \\
political \\
participation
\end{tabular} & $\begin{array}{l}\text { Social } \\
\text { inclusion }\end{array}$ \\
\hline \multirow[t]{2}{*}{ Spearman's rho } & $\begin{array}{l}\text { Youth } \\
\text { political } \\
\text { participation }\end{array}$ & $\begin{array}{l}\text { Correlation Coefficient } \\
\text { Sig. (2-tailed) } \\
\text { N }\end{array}$ & $\begin{array}{r}1.000 \\
\cdot \\
1208\end{array}$ & $\begin{array}{r}.875^{*} \\
.000 \\
1208\end{array}$ \\
\hline & $\begin{array}{l}\text { Social } \\
\text { inclusion }\end{array}$ & $\begin{array}{l}\text { Correlation Coefficient } \\
\text { Sig. (2-tailed) } \\
\mathrm{N}\end{array}$ & $\begin{array}{r}.875^{*} \\
.000 \\
1208\end{array}$ & $\begin{array}{r}1.000 \\
. \\
1208\end{array}$ \\
\hline
\end{tabular}

*. Correlation is significant at the 0.05 level (2-tailed).

The result support the hypothesis that there is a relationship between youth political participation and good governance in Nigeria. To ensure that good governance is engendered, it is imperative to improve youths' involvement and participation in politics. It is believed that doing so will improve transparency and accountability in the system, promote economic and political development, curb corruption, and provide the impetus to combat multidimensional poverty in Nigeria. Furthermore, the study presented in this paper supports the argument that youth political participation will lead to social inclusion in Nigeria. The indices of social exclusion such as deprivation, marginalization, and gender inequality can be adequately combated by youth. With increased youth involvement, human capital will be enhanced and a 
better life will be assured, which will in turn promote an inclusive society. The findings of this study is consistent with the view of several other authors. According to Tekindal (2017), youth political participation can positively impact a society, and even an organization. Checkoway \& Schuster (2003) conclude that youth political participation will empower youth with the knowledge to maximize their political rights, help them democratize, and allow integrated inclusion. Arches \& Fleming (2006) also opine that political participation will grant youth the skills to become active citizens and contribute meaningfully to governance and development. Of course, when socially included, youth have the potential to bring about entrepreneurship, innovation, and advancement, which is particularly needed in the agricultural sector - an area that has been neglected by youth.

\section{Conclusion and Recommendations}

The study found out that youth political participation has a positive correlation with good governance and social inclusion in Nigeria. The study revealed that the majority of Nigerian youth are unemployed even though a larger percentage of them have either attained or presently undergoing post-secondary education. It is therefore important that attention be paid to youth involvement in politics, because as this study indicates, their involvement will promote good governance, especially in the areas of transparency, accountability, and development. In a like manner, their involvement in politics will effectively address inequity and exclusion to create an inclusive society.

In view of these findings, the study hereby recommends that the Nigerian should make reaffirm her commitment to the 'Not too Young to run' legislation. In more explicit terms, the government should create Leadership and Democratic Institutes (LDI) across the states of the federation to train youth in the art of governance and prepare them for leadership. When youth perceive that their opinion counts and that government takes interest in their political futures, they will be spurred to participate more actively in politics.

More so, government under the aegis of the Ministry of Youth and Sport, should take advantage of the technological prowess of the youth by creating an Online Leadership Orientation Agency [OLOA] using various social networking sites to provide free leadership courses, webinars, and orientation on the art of governance and promotion of social inclusion among youth. Doing this, will increase their interest in government, rekindle their trust in the process, and of course, increase their participation in political activities.

In addition, the curriculum of primary, secondary and tertiary institutions should be revised to reflect compulsory Political, Governance and Leadership Education [PGL] courses political leadership courses that will be given equal treatment as core subjects like Mathematics and English. This is because with adequate knowledge of the political process, governance and politics, youth will be encouraged to participate more in politics as they grow.

Youth are also advised to engage with themselves more on social media as to engender capacity building and new world order of political participation in Nigerian politics.

Finally, government should make frantic efforts to entrench social inclusion in the country by combating poverty, inequality, deprivation and marginalization. Government should do this by investing more in the human capital development of youth. 


\section{References}

Abdelrahim, Y. (2019). Tribalism and corruption: explorations beyond national culture and scale construction. A dissertation presented to the graduate faculty of the University of Wisconsin for award of Doctor of Business Administration.

Adegbami, A. \& Adepoju, B. (2017). Good governance in Nigeria: A catalyst to national peace, stability and development. African Research Review, 11(4), 144-155

Akinyetun, T. S. (2016). Bridging the researcher-respondent divide: Role of internet-based survey. International Journal of Academic Research in Education and Review, 4(4), $116-126$

Alexa (April 23, 2020). Top sites in Nigeria, Alexa page rank, 23 April 2020, Retrieved from www.alexa.com

Badmus, B. (June 4, 2018). 2019: Nigerian youths more than prepared for leadership -Young Alliance. Nigerian Tribune. Retrieved from https://tribuneonlineng.com/2019-nigerian-youths-more-than-prepared-for-leadership$\%$ E2\%80\%95young-alliance/

Checkoway, B. and Schuster, K. (2003). Youth participation in community evaluation research. American Journal of Evaluation, 24(1), 21-33.

Department for International Development (2010). Youth participation in development: A guide for development agencies and policymakers. $U K$ Department for International Development. Retrieved from http://www.restlessassets.org/wl/?id=umaETRcmVyn2VEpSrxu7JWWkHom 5RYli

Edwards, K. (2008). Social inclusion and youth participation: a new deal for Australia's young people? Youth Studies Australia, 27(2), 11-17

EU-Council of Europe youth partnership (2019). Glossary on youth. Retrieved from available at www.pjp-eu.coe.int/en/web/youth-partnership/glossary

Farthing R. (2012). Why youth participation? Some justifications and critiques of youth participation using new labour's youth policies as a case study. Youth \& Policy

Galstyan, M. (2019). Youth political participation: Literature review. European Commission

Hilker, L. M. \& Fraser E. M. (2009). Youth exclusion, violence, conflict and fragile states. Report prepared for DFID by Social Development Direct, London. Retrieved from http://www.gsdrc.org/document-library/youth-exclusion-violenceconflict-and-fragilestates/

Ibezim, E. A. (2019). The philosophy of youth inclusion in Nigerian politics: Trend, challenges and prospect. Journal of Religion and Human Relations, 11(1), 119-136

Luhrmann, A. (2013). Enhancing youth political participation throughout the electoral cycle. New York: United Nations Development Programme.

Mengistu, M. M. (2017). The quest for youth inclusion in the African politics: Trends, challenges, and prospects. Journal of Socialomics, 6(1), 1-5

Nairaland Forum. Retrieved from https://www.nairaland.com

National Bureau of Statistics (2018). 2017 Demographic statistics bulletin. Not Available

National Youth Policy (2019). Enhancing youth development and participation in the context of sustainable development. Retrieved from https://youthandsport.gov.ng/wpcontent/uploads/2018/01/Youth-Policy.pdf 
O'Toole, T. (2015). Beyond crisis narratives: changing modes and repertoires of political participation among young people. In K. Kallio, S. Mills, \& T. Skelton T (Eds.) Politics, citizenship and rights. Singapore: Springer.

Obi, G. O. (May 2, 2020). Top 20 local websites in Nigeria in 2020. IABC Africa. Retrieved from www.iabcafrica.com. IABC Africa.

Offiong, I. (March 22, 2018). Youth not yet ready for leadership role. The Nigerian Voice. Retrieved from https://www.thenigerianvoice.com/news/264685/youth-not-yet-readyfor-leadership-role.html

Olufowobi, S. (June 4, 2018). Nigerian youths ready for leadership -Young Alliance. Punch. Retrieved from https://punchng.com/nigerian-youths-ready-for-leadership-youngalliance/

Ozer, Y. E. (2011). Youth participation in social life and the role of local governments. Journal of Eylul, 26(1), 43-65

Pleyers G. and Karbach N. (July 2014). Analytical paper on youth participation - Young people political participation in Europe: What do we mean by participation? Strasbourg: Council of Europe Publishing

Pontes, A., Henn, M. \& Griffiths, M. (2019). Youth political (dis)engagement and the need for citizenship education: Encouraging young people's civic and political participation through the curriculum. Education, Citizenship and Social Justice, 14(1), 3-21

Rhize. (2016). The new global citizen: Harnessing youth leadership to reshape civil society. Rhize. Retrieved from http://www.rhize.org/newglobalcitizen/

Sida (2010). Young people's political participation. Retrieved from https://www.sida.se/contentassets/a06826186ce9459d9cd91538e0c18e6b/15043.pdf

Tekindal, M. (2017). The position of the youth in political participation. Journal of Social Policy Studies, 39, 119-140

Udeh, G. N. (2017). Democracy and good governance in Nigeria: The imperatives of supporting institutions. Asian Development Policy Review, 5(3), 148-158

United Nations (2013). Youth political participation and decision-making. Retrieved from https://www.un.org/esa/socdev/documents/youth/fact-sheets/youth-politicalparticipation.pdf

United Nations (2016). Leaving no one behind: the imperative of inclusive development. ST/ESA/362. Retrieved from https://www.un.org/esa/socdev/rwss/2016/fullreport.pdf

United Nations Development Programme (2014). Human development report 2014. New York: UNDP.

United Nations Educational Scientific and Cultural Organization (2013). World radio day, statistics on youth. UNESCO. Retrieved from http://www.unesco.org/new/en/unesco/events/prizesandcelebrations/celebrations/international-days/world-radio-day-2013/statistics-on-youth/

van Deth, J. W. (2014). A conceptual map of political participation. Acta Politica, 49, 349367.

Verba, S. \& Nie, N. H. (1972). Participation in America. Political democracy and social equality. New York, NY: Harper and Row.

World Bank (2013). Inclusion matters: The foundation for shared prosperity. Washington, DC.

Zohdy, N. (2017). Examining why and how to engage young people in global development: A literature review. World Bank Group. 